> Gi rask respons på artikler gjennom artikkelens kommentarfelt på tidsskriftet.no. Respons som er postet innen én måned etter at artikkelen er publisert, vurderes for publisering som Brev til redaktøren i papirutgaven.

Redaksjonen forbeholder seg retten til å foreta redaksjonelle endringer.

Forfattere av vitenskapelige artikler har tilsvarsrett, jf. Vancouver-gruppens regler.

\section{Trygg barseltid for nyfødte barn}

I Tidsskriftet nr. 3/2013 omtaler Stefan Kutzsche \& Drude Fugelseth Helsedirektoratets høringsutkast om nye retningslinjer for barselomsorgen (1). I høringsutkastet foreslås det å tilby nyfødte pulsoksymetri for å oppdage alvorlig medfødt hjertefeil, men under «dokumentasjon» angir de at dette er en svak anbefaling (2). I en nylig gjennomgang av 552 studier der 13 gode og store nok studier ble plukket ut, fant man at screening med pulsoksymeter oppdaget okkult alvorlig hjertefeil med en sensitivitet på 76,5\% og spesifisitet på $99,9 \%$ (3). Falskt positive tester som førte til unødvendig undersøkelse med ekkokardiografi tilsvarte $0,14 \%$. Spesielt for barn med transposisjon av de store kar er screening med pulsoksymeter av betydning, idet disse barna sjelden oppdages ved intrauterin diagnostikk, hjertefeilen er potensielt en dødelig tilstand og behandlingstilbudet ved tidlig diagnostikk er meget godt. Pulsoksymeterscreening har lav kostnad, gir intet ubehag for barnet og kan med letthet innføres som rutine på enhver barselavdeling i Norge. Det er vanskelig å forstå hvorfor ikke høringsutkastet vil gi en sterkere anbefaling, men det er å håpe at sykehusene allikevel vil følge opp.

Leif Brunvand

leifbrunvand@hotmail.com

Leif Brunvand (f. 1953) er dr.med og overlege ved Kvinne- og barneklinikken, Oslo universitetssykehus.

Ingen oppgitte interessekonflikter.

\section{Litteratur}

1. Kutzsche S, Fugelseth D. Trygg barseltid for nyfødte barn. Tidsskr Nor Legeforen 2013; 133: 270 .

2. Høringsutkast - retningslinje for barselomsorgen. Nytt liv og trygg barseltid for familien. Oslo: Helsedirektoratet, 2012. http://helsedirektoratet.no/0m/ hoyringar/Documents/barselomsorg/H\%C3\%B8ringsutkast.Retningslinje\% 20for\%20barselomsorg.pdf (10.1.2013).

3. Thangaratinam S, Brown K, Zamora J et al. Pulse oximetry screening for critical congenital heart defects in asymptomatic newborn babies: a systematic review and meta-analysis. Lancet 2012; 379: 2459-64.

Dette er en redigert versjon av et innlegg publisert som rask respons på nett 3.2. 2013 http://tidsskriftet.no/article/2965565/

\section{Medisinerte forsøksobjekter}

I Tidsskriftet nr. 3/2013 omtaler Erlend Hem (1) en studie der Ingrid Dieset og medarbeidere har funnet økt ekspresjon av immunrelatert gen hos pasienter med bipolar lidelse (2). Det kommer ikke frem av artikkelen hvor stor del av forsøkspersonene som var medisinert. Dersom de var medisinerte, hvordan vet man da at medisineringen ikke påvirker resultatet?

I omtalen av artikkelen oppgis det at schizofreni og bipolar lidelse er komplekse sykdommer med opp mot $80 \%$ arvelighet men det oppgis ingen referanse. Det er ikke lenge siden arveligheten ved bipolar lidelse ble beregnet til rundt $20 \%$. Hva kan ligge bak denne dramatiske økningen $\mathrm{i}$ arvelighet?

\section{Lasse Bøyum}

lasseboyum@gmail.com

Lasse Bøyum (f. 1962) er filosof.

Ingen oppgitte interessekonflikter.
Litteratur

1. Hem E. Inflammasjonsmarkører ved bipolar lidelse. Tidsskr Nor Legeforen 2013; 133: 274

2. Dieset I, Djurovic S, Tesli M et al. Up-regulation of NOTCH4 gene expression in bipolar disorder. Am J Psychiatry 2012; 169: 1292-300.

Dette er en redigert versjon av et innlegg publisert som rask respons på nett 19.1. 2013 http://tidsskriftet.no/article/2965717

\section{Spørsmål om inflammasjonsmarkører ved bipolar lidelse}

I Tidsskriftet nr. 3/2013 omtaler Hem (1) en norsk studie av Ingrid Dieset og medarbeidere om inflammasjonsmarkører ved bipolar lidelse (2). Det er interessant at det forskes på psykoseproblematikk. Som en med personlig erfaring med psykose er jeg opptatt av psykososiale problemstillinger. Jeg har et par spørsmål til studien. For det første lurer jeg på hva som hva ligger i uttrykket: «Nye angrepspunkter for medikamentell behandling?» For det andre skulle jeg gjerne ha visst hvorvidt dette er en studie der pasientgruppen selv har vært med på å formulere problemstilling?

\section{Siv Helen Rydheim \\ sivryd@gmail.com}

Siv Helen Rydheim (f. 1955) er tvangs- og psykoseerfarer, forfatter og student ved videreutdanning i samarbeidsbasert forskning. Ingen oppgitte interessekonflikter.

Litteratur

1. Hem E. Inflammasjonsmarkører ved bipolar lidelse. Tidsskr Nor Legeforen 2013; 133: 274

2. Dieset I, Djurovic S, Tesli M et al. Up-regulation of NOTCH4 gene expression in bipolar disorder. Am J Psychiatry 2012; 169: 1292-300.

Dette er en redigert versjon av et innlegg publisert som rask respons på nett 19.1. 2013 http://tidsskriftet.no/article/2965717

\section{Dieset svarer:}

Vi takker for gode innspill fra Lasse Bøyum og Siv Helen Rydheim på vår studie Up-regulation of NOTCH4 gene expression in bipolar disorder som sto omtalt i Tidsskriftet nr. 3/2012 (1).

Bøyum peker på et meget viktig moment som alltid er relevant i slike studier, nemlig effekten av medisiner. Vi undersøkte effekten av medisiner i denne studien og fant at Lamictal hadde en liten effekt på ekspresjonen av NOTCH4-genet, vi kontrollerte derfor for effekten av Lamictal i alle analysene. Vi undersøkte også effekten av andre typer medisiner, men fant at disse ikke hadde noen innvirkning på ekspresjonen av dette genet (se tabell $1 \mathrm{i}$ artikkelen og tabell S1 og S2 i supplementmaterialet).

Videre setter Lasse Bøyum spørsmålstegn ved at arveligheten for bipolar lidelse er estimert til $80 \%$ (2). Med arvelighet mener vi et estimat på hvor mye gener kan forklare av variansen på gruppenivå.

Denne studien utgår fra et større prosjekt ved K.G. Jebsen senter for psykoseforskning. Vi undersøker flere ulike problemstillinger knyttet til schizofreni og bipolar lidelse, og noen av våre kolleger ser også på psykososiale problemstillinger. Mange pasienter med schizofreni og bipolar lidelse har delt sin kunnskap om sykdommen med oss, og uten denne informasjonen fra pasientene selv ville vi ikke kunnet formulere relevante problemstillinger.

Rydheim stiller spørsmål om pasientgruppen har vært med på 
å formulere problemstillingen. Når det gjelder dette underprosjektet som undersøker potensielle immunologiske mekanismer ved schizofreni og bipolar lidelse, er de konkrete problemstillingene utarbeidet av forskerne. Pasientgruppen har imidlertid i aller høyeste grad bidratt $\mathrm{i}$ denne prosessen ved å dele sin kunnskap med forskerne. Noen pasienter som bruker medisiner rapporterer lite effekt og/eller bivirkninger og ville kanskje hatt glede av nye og bedre medisiner. Basert på disse tilbakemeldingene er hovedmålet med prosjektet å undersøke potensielt nye biologiske mekanismer som kanskje vil kunne danne grunnlaget for å utvikle nye medisiner i fremtiden.

Ingrid Dieset

ingrid.dieset@medisin.uio.no

Ingrid Dieset (f. 1971) er overlege ved K.G. Jebsen senter for psykoseforskning.

Oppgitte interessekonflikter: Forfatter har mottatt honorar for foredrag på Akuttpsykiatrikonferansen 2012, og institusjonen har mottatt støtte fra Helse Sør-Øst og Norges forskningsråd.

Litteratur

1. Dieset I, Djurovic S, Tesli M et al. Up-regulation of NOTCH4 gene expression in bipolar disorder. Am J Psychiatry 2012: 169: 1292-300.

2. Craddock N, Sklar P. Genetics of bipolar disorder: successful start to a long journey. Trends Genet 2009; 25: 99-105

\section{Adrenalin ved avansert hjerte-lunge-redning?}

I Tidsskriftet nr. 3/2013 omtaler Ingrid Rokstad en studie av Theresa M. Olasveengen og medarbeidere som viser at adrenalin gir høyere dødelighet ved hjerte-lunge-redning (1). Dette er spennende og viktig forskning fra et ledende norsk forskningssenter (2). Det blir interessant å se om andre/nye studier kan bekrefte disse resultatene og om de får følger for de neste internasjonale retningslinjene for avansert hjerte-lunge-redning som planlegges i 2015. Antakelig må flere studier til før International Liaison Committee on Resuscitation (ILCOR) og European Resuscitation Council (ERC) konkluderer om man skal gå bort fra anbefalingen om adrenalin som standardmedikament ved avansert hjerte-lunge-redning eller eventuelt anbefale en justert (redusert?) dose. Norsk Resuscitasjonsråd (NRR) vil på dette punktet forholde seg til hva de internasjonale retningslinjene til enhver tid sier. Hvis man kommer til å konkludere med å ta bort adrenalin som anbefalt rutinemedikament ved avansert hjerte-lungeredning, vil dette føre til en ytterligere forenkling av hjertestansbehandlingen.

\section{Kristian Lexow}

kristian.lexow@lyse.net

Kristian Lexow (f. 1952) er overlege ved Stavanger universitetssjukehus og leder av Norsk Resuscitasjonsråd.

Ingen oppgitte interessekonflikter

\footnotetext{
Litteratur

1. Rokstad IS. Adrenalin ved hjerte-lunge-redning gir høyere dødelighet. Tidsskr Nor Legeforen 2013; 133: 277.

2. Olasveengen TM, Wik L, Sunde $K$ et al. Outcome when adrenaline (epinephrine) was actually given vs. not given - post hoc analysis of a randomized clinical trial. Resuscitation 2012; 83: 327-32.
}

Dette er en redigert versjon av et innlegg publisert som rask respons på nett 23.1.2013 http://tidsskriftet.no/article/2965901

\section{Avansert hjerte-lunge-redning og adrenalin}

I Tidsskriftet nr. 3/2013 omtaler Ingrid Rokstad (1) en svært interessant studie som føyer seg inn i rekken av flere studier der man har satt spørsmålstegn ved nytten av å gi adrenalin intravenøst under resuscitering. Jeg stiller meg imidlertid ett spørsmål: Er det mulig at dosen $1 \mathrm{mg}$ adrenalin som man har hatt for vane å gi i repeterte doser ved resuscitering av voksne, er for høy? Kunne man tenke seg andre resultater ved doser på f.eks. $0,1 \mathrm{mg}$ ? Kan det med andre ord være doseringen det er noe «galt» med og ikke medikamentet per se?

\section{Dag Strand}

dagstrand@hotmail.com

Dag Strand (f. 1965) er spesialist i anestesiologi og ansvarlig anestesilege ved Teres Stokkan, Trondheim.

Ingen oppgitte interessekonflikter.

\author{
Litteratur \\ 1. Rokstad IS. Adrenalin ved hjerte-lunge-redning gir høyere dødelighet. Tidsskr \\ Nor Legeforen 2013; 133: 277.
}

Dette er en redigert versjon av et innlegg publisert som rask respons på nett 8.1. 2013 http://tidsskriftet.no/article/2965901

\section{Kontekstavhengig journalføring}

I Tidsskriftet nr. 3/2013 har Jan H. Dobloug og medarbeidere en interessant kommentar om legen som sakkyndig i forsikringssaker (1). Jeg opplever dette som engasjerende og er enig i redaksjonens vurdering av at prinsippet om samtykke måtte fravikes her på grunn av sakens store samfunnsinteresse (2). Særlig lesingen av sak 4 i Doblougs artikkel (1) får meg til undre hva jeg selv kunne gjort i førstelinjetjenesten. I en situasjon med bekymring og usikkerhet kan det friste å smøre litt tykt på for å gi «min» pasient raskere vurdering hos nevrolog. I en sakkyndig uttalelse til forsikringsselskap kan jeg kanskje trekkes i motsatt retning: Jeg vil ikke forskuttere konklusjonen av en henvisning jeg kanskje innerst inne ikke følte var berettiget. Idealet er selvfølgelig å drive sin praksis med så stø hånd at saksinnholdet $\mathrm{i}$ en henvisning ikke skiller seg nevneverdig fra en sakkyndig uttalelse om helsetilstand.

I en hverdag der medfølelse og innlevelse er av det gode, kan det være krevende å være sakkyndig med all den nøkternhet og kulde det medfører. Jeg opplever god støtte i helsepersonellovens påbud om å gjøre pasienten oppmerksom på hva oppdraget som sakkyndig innebærer (3). Slik gjør jeg det klart for pasienten og meg selv at det skal foregå noe annet enn helsehjelp. Jeg er imidlertid tvilende til hvorvidt helsevesenet bør yte hjelp til forsikringsselskaper slik at de kan gjøre en risikostratifisering av sine kunder. Eksemplene Dobloug refererer viser alle at pasientjournaler kan innhentes ved tvil (1). Jeg ser sakkyndig helseerklæring før inngåelse av forsikring som en sikring av forsikringsselskapets overskudd. Min konklusjon blir derfor at forsikringsselskapene heller bør spre denne risikoen utover sine kunder og kun basere seg på en egenerklæring.

Det kan bli krevende å få slutt på gjeldende praksis. I førstelinjen fikk jeg godt betalt for å fylle ut skjema for forsikringsselskapene, og forsikringsselskapene tjener gode penger på å holde risikokundene unna.

\section{Sindre Gunleiksrud \\ sindre.gunleiksrud@gmail.com}

Sindre Gunleiksrud (f. 1983) er lege i spesialisering ved Universitetssykehuset Nord-Norge, Narvik.

Oppgitte interessekonflikter: Forfatter eier aksjer i Gjensidige Forsikring. 